\title{
ASSESSMENT OF THE INFLUENCE OF ON-CAMPUS HOUSING QUALITY AND FACILITIES ON STUDENTS' ACADEMIC PERFORMANCE AT THE FEDERAL UNIVERSITY OF TECHNOLOGY, AKURE, NIGERIA
}

\author{
David Ngwoke MBAZOR* \\ Federal University of Technology, Akure, Nigeria \\ Corresponding author's e-mail:dnmbazor@futa.edu.ng
}

\begin{abstract}
The management of federal universities in Nigeria has not taken the issue of students' housing provision as a priority. Hence, demand for on-campus housing accommodations far exceeds the supply and this resulted in the majority of the students living in private residences characterised by poor facilities. This study, therefore, assessed the housing quality and facilities in the undergraduate student's hostels at the Federal University of Technology, Akure, Nigeria to investigate its suitability for learning and research. A simple random sampling technique was used for the study. Data were collated from both primary and secondary sources. The data collected were analysed using frequency tables and weighted mean scores for estimating the Housing Quality Indices (HQI) according to a 5-point Likert scale. The academic performance of the occupants before and after moving to the university hostel was equally investigated using a regression analysis to test if a relationship exists among the housing quality, the quality of facilities provided and the academic performances of the students. The result revealed a positive relationship between the academic performance of the students and the quality of housing facilities. A comprehensive maintenance programme of the students' accommodation within the university campus is recommended for higher academic performance. The study contributes to the body of knowledge in academic performance of students, developing and managing students' accommodation quality at higher education institutions.
\end{abstract}

Keywords: Academic performance; Housing; Facilities; Housing quality; On-campus housing; University.

\section{INTRODUCTION}

Historically, University has its origin from the Medieval Cities of Paris and Oxford around $1200 \mathrm{AD}$ (Bender, 1988). University education attracts staff and students of various ethnic and socio-cultural backgrounds all over the world for learning and research. In the early years of university education, provisions were not made for students to live inside the university campuses, rather they lived among the local community within the vicinity of the university (Caldenby, 1994). 
In the process of time, the scenario changed when the owners of the universities realised that students' housing was part of students' social life.

In Nigeria, soon after the country got the independence in 1960, there was a dare need to establish more universities to train manpower for the development of the new nation. This brought about the establishment of several universities such as Ahmadu Bello University, Zaria in 1962, University of Lagos, 1962, University of Benin, 1970, etc. In each of these universities, all the students were accommodated in campus, but this could not be sustained as the population of students went beyond the number of accommodation provided in the campuses. As a result of the upsurge in the students' population, those who could not secure on-campus housing had no choice than to live in the privately-owned accommodation outside the university premises.

The availability and affordability of quality housing in developing countries such as Nigeria is very worrisome and poses a great concern and burden to the state and individual members of the society. Therefore, there is a need for urgent attention to the development of quality housing in the country to meet the sustainable development goal of decent accommodation for all in 2030. However, this concern is primarily because the influence that quality residential housing has on the performance and productivity of occupants is enormous. Hence, Morris, Winter, and Murphy (1988) noted that a person's home played a key role in influencing his/her productive capacity. It, therefore, suggests that the living place of a man is central to his daily life and is responsible for the increase or decrease of his productivity and performance.

Quality housing unit or accommodation is essential to everybody, including students, because it is where a man retreats after going through the stress brought upon them by the demands of daily living (Ebie, 2009). The issue of availability of quality housing has formed part of major discussions in national and global summits such as the 1992 Rio-de Janeiro Summit on Environment and Development, the 1996 Habitat Summit at Instanbul, 2002 World Summit in Johannesburg and the 2002 La Havana Summit, etc. According to Jacobs (2002), quality housing is a key element for determining and ensuring a dynamic society. The study further notes that the absence of quality in a house leads to many health complications such as respiratory diseases and severe infections. It may also result in stress and depression. On the other hand, Kuh et al. (2006) discovered that quality housing significantly affected the self-esteem and psychology of the occupant which also would have impact on the performance and productivity of the occupant. Ebong (1983) stated that quality residential housing was evidenced by indoor environmental quality usually determined by many factors such as daylighting, ventilation (air quality), damp conditions, as well as the condition of sanitary and drainage systems.

The need for efficient and conducive students' housing facilities at higher education institutions cannot be overemphasised because students need to maintain a sound state of mind in a decent living environment to excel in their academic endeavors. Hence, students' academic performance is directly related to their housing situation (Aluko and Ola 2011). Observation shows that students' academic performance in Nigeria is declining and this unfortunate situation is attributed to 
the conditions of the houses they reside in, both within and outside the campuses. The situation of students' housing in Nigeria as well as in other developing coutries is poor (Centre for Global Education, 2002). There is a sharp contrast compared to developed countries, such as the UK, the USA, Canada, etc. In these countries, sufficient attention is given to the provision of quality on-campus accommodation to meet students' accommodation needs. The houses are equipped with sufficient and functional state-of-the-art facilities, they are situated in a well-defined environment, and contain facilities that satisfy the UN's minimum reccommendations for quality housing.

This study aims at assessing the influence of the quality of accommodation as provided on the academic performance of the resident students of the Federal University of Technology, Akure Nigeria. Quality housing is arguably one of the basic needs of a man. Housing, according to Ebie (2009), used to be ranked second after food using man's hierarchy of needs. However, now it is ranked first and is the most important right of all humans. Hanmer, Booth and Love (2000) observed that qualitative housing involved the provision of services that could bring about sustainable growth and development through improved environmental conditions and good livelihood.

Performance assessment in all areas of endevour has been a topic of serious discussion. The performance of an individual can be measured based on the outcome/result of his or her job performance; self-satisfaction, achievements and other factors (Hofstede, 1984). Various studies, including Aluko and Ola (2011), Owolabi (2015), Adeleye, Akinpelu and Azeez (2018), have examined different aspects of performance, including student performance, economic performance, organisational performance, and societal performance. Only very few studies have examined students' academic performance in relation to housing quality. Studies have shown that much work has not been undertaken in the area of housing facilities that influence the performance of students (Hunley, 2006). Some of the past studies on student's housing performance include Foubert, Tepper and Morrison (1998) in the United States of America and Khozaei, Ayub, Hassan, and Khozaei (2010) in Malaysia. Other similar studies include Kaya and Erkip (2001) who evaluated the satisfaction of students' housing quality in Turkey. Similarly, Hassanain (2008) examined the housing quality in terms of thermal, technical, and functional performances. However, Amole (2009) examined the features of halls of students' residences in Nigerian universities that would match the levels of housing satisfaction among students. On the other hand, Dahlan et al. (2009) adopted a narrow focus on specific aspects of student housing satisfaction that affected their performance, namely, visual comfort, thermal comfort, etc. Again, Khozaei et al. (2010) investigated the relationship between students' satisfaction and sense of attachment to a particular housing type. Most previous studies did not address a broad spectrum of the influence of housing quality/facilities on students' academic performance. For this reason the present study takes a holistic approach to examine the influence of housing quality on students' academic performance at the Federal University of Technology, Akure, Nigeria.

Studies have shown that in the environments of higher education institutions as we have them today the desire of students to live in decent on-campus housing fitted 
with adequate facilities has significantly increased (Najib and Yusof, 2009; Khozaei, Ayub, Hassan, and Khozaei, 2010). Susilawati (2001) noted that providing modern facilities in students' housing was essential to meet their needs and to ensure good academic performance. Past studies have identified some specific housing features that influence the productivity and satisfaction of occupants. Olujimi and Bello (2009) stated that the availability of bathroom, study room, kitchen and other essential features were seen as the necessities in on-campus housing. On the other hand, Schenke (2008) highlights the high premium placed on the internet connectivity, either through network connection or Wi-Fi, in the students' halls of residence. In the opinion of Torres-Antonini and Park (2008), facilities that are used jointly such as laundry rooms, kitchens area, common study room, etc. are essential for the overall development of students. Similarly, Abramson (2009) identified amenities such as parking spaces, mini markets, clinics, coffee shops, and banks, etc. as essential things that should be provided in students' on-campus housing to enhance their academic performance. Given the narrow focus of these studies as seen above, another study is imminent to investigate the influence of housing quality on students' academic performance.

The main question addressed in this study is: How can accommodation facilities influence students' academic performance? The main aim of the study is to investigate the relationship between students' housing quality and the overall academic performance, while the specific objectives are to analyse the condition of facilities provided in the students' hall of residence in the study area, and to determine the ifluence of facilities as provided in the halls of residence on the students' academic performace.

The outcomes of this study will help educational policy makers and management in identifying strategic educational facilities to focus in order to actualise their overall aim.

\section{The Study Area}

The choice of Federal University of Technology, Akure (FUTA) is perfect for a study like this, given that the University has a reasonable number of on-campus accommodations situated within the premises of the University for students' occupation; facilities of diverse nature and quality are available for use by students; there are students of different academic programmes and levels at the University. Moreover, the University has a high concentration of both male and female students from different cultural and religious backgrounds residing in the University hostels. Given that the University aspires to be a world-class university, a study of this nature becomes important to enable the University and all stakeholders particularly those concerned with students' housing to understand the existing students' housing conditions at the university, thereby ensuring the achievement of the University goal through improving and sustaining students' academic performance. 


\section{Significance of the Study}

Providing quality on-campus residential houses in a cuisine environment for students is an important motivating factor to encourage them to live comfortably and perform creditably in their studies. Hence, Amole (2009) stated that satisfaction with on-campus students' housing was an important indicator in measuring the quality of students' living environments and their academic performance. However, other studies examined higher education institutions in Nigeria, and they include Mbano, Alaka and Ewulum, (2012), Mbano, Alaka and Okeoma (2012), DejiFolutile and Oketola (2014), Oluwunmi, Akinjare and Izobo (2012). None of these studies focused on the influence of housing quality on students' performance. This study, therefore, contributes to knowledge by expanding a study on satisfaction of students' housing as examined by Oluwunmi, Akinjare and Izobo (2012) to include the influence of housing quality on students' academic performance. The results also provide insights for academic quality assurance managers and facility managers at the universities. This study will further enable universities to improve their services and offer better on-campus housing facilities in years to come. The results will also help the management team to develop strong strategic policies that will provide world-class students in the $21^{\text {st }}$ century.

\section{LITERATURE REVIEW}

Housing is one of the most important human needs and rights. Ebie (2009) argues that it is the most fundamental need of a man. It proves the level of importance people attach to housing. Agbola and Oladoja (1998) states that residential housing includes a combination of characteristics that provide a unique home for a person or persons within a neighbourhood in the form of single-family detached units, duplexes, row-houses, mansion apartments, cottage courts, walkup apartments, etc. Ndubueze (2001) opines that housing units provide a place where a man retreats to rest from the stress of the daily activities and commune with family members. United Nations (2003) noted that housing went beyond having a roof over one's head but included several other ancillary services and utilities such as water, electricity, road, etc. Brkanic (2017) observed that there were several numbers of defined criteria for assessing housing quality, and four groups of assessment criteria were identified: apartment unit quality, apartment building quality, neighbourhood quality, and social and economic criteria. The study further stated that the defined criteria could be divided according to the different scales of the assessed spaces (apartment unit, building, and neighbourhood), and according to the method of assessment (quantitative or qualitative).

The housing situation in Nigeria like in other developing nations is characterised by numerous inadequacies, which are quantitative and qualitative. Oladapo (2006) in a study on housing quality observed that the quality of houses in urban and semi-urban places was unevenly distributed and the available few were affordable only to the insignificant percentage of the population who were either politicians or elites in the society. Ezeigwe (2015) identified failure on the part of government and agencies to implement the housing policies, high building cost, 
corruption on the part of stakeholders, staff and student population increase and unavailability of land both in public and private universities in Nigeria. Ebong (1983) and Onibokun (1990) also agreed that residential housing should possess some basic quality characteristics to guarantee attraction to prospective users and enhance utilisation for the achievement of the predetermined goals for which they were provided. Such characteristics according to the studies include good housing design, adequate ventilation, proper lighting, good drainage channel system, regular sanitation, security, not overcrowded, adequate water supply, and good road accessibility.

Meng and Hall (2006) in a study on residential housing quality assessment and measurement stated that housing quality connoted the level of occupants' acceptability of dwelling units and the surrounding environment which included the design outlook and functionality of structures, nature of materials used, space utilisation, utilities and services provided in the units. Okewole and Aribigbola (2006) corroborated this assertion in a study on innovations and sustainability in housing policy conception and implementation in Nigeria by observing that housing quality was assessed using factors such as the physical condition of a house, internal and external facilities and services available in a house and other features that make living in an environment conducive. Therefore, it can be deduced from the studies that housing quality is measured by the amount of satisfaction in terms of health, enjoyment and living standards of users.

However, Danes and Morris (1986) in a study on housing status, housing expenditures and satisfaction with housing quality found the ceiling on housing quality assessment. The study found that this ceiling in turn influenced users' satisfaction and concluded that once a user reached the highest level of satisfaction, they derived little additional satisfaction from a further increase in quality variables. Hence, Morris, Winter and Murphy (1988) in a study on housing adjustment, satisfaction and quality considerations stated that "high quality of facilities and services in large dwellings produces high level of housing satisfaction". Thus, it can be inferred from the studies that the level of housing quality is directly related to the amount of satisfaction derived from the occupants. Where the housing unit or domain can satisfy the occupants' needs to a reasonable level, it is believed that such a domain is of reasonable quality. If, on the other hand, the domain fails to satisfy the occupants' needs and aspirations, such a dwelling can be said to be of low quality.

Drawing from the above assertions, Park (1988) found a relationship between the income level of a family and their level of satisfaction with their accommodation units. The study revealed that the level of income of a family determined the quality of the dwelling unit needed. Specific parameters were identified by researchers as indicators to look out for in determining quality housing. Adriannse (2007) in agreement with Kellekci and Berkoz (2006) noted that housing satisfaction was one of the key instruments indicating the quality of housing. Longman (2003) defined satisfaction as "a feeling of happiness or pleasure achieved or got from the use of a property". Neilson (2004) identified five criteria that a quality dwelling must meet, and they include compliance with acceptable standards; free from dilapidation; energy efficient; healthy; safe, secure and modern functional facilities. 
Similarly, Hanmer et al. (2000) observed that qualitative housing connotes the provision of housing services for sustainable economic and social growth through better environmental conditions and livelihood. Meng and Hall (2006) also identified four criteria for identifying quality housing, namely: objective, scientific, management and socio-cultural criteria. Each of the criteria has its specific considerations that govern the selection of quality indicators. The effects of oncampus housing conditions on student's performance in most cases are usually indirect. As such, the housing conditions usually act on the health and psychology of the students which would eventually have a grave impact on their academic performance. According to the World Health Organization Guideline for Healthy Housing (1988), deficient housing affects occupants' physical health in three major ways. It facilitates the transmission of communicable diseases; it interferes with the physiological needs of the occupants and its design or construction causes injury to the occupant. This was re-emphasised by the Chartered Institute of Environmental Health (2008) and the UK House of Parliament (2011) which stated that "poor housing condition is associated with Cardiovascular diseases, Respiratory diseases; Depression and anxiety, Rheumatoid arthritis, Nausea and Diarrhoea, Infections, Allergic symptoms, Hypothermia, Physical injury from accidents and Food poisoning, etc." This condition explains why there is poor output of workers and students at some universities when compared to others. Similarly, Agbo, Envuladu, Adah, and Zoakah (2012) noted that certain health conditions such as Cholera, Typhoid, Diarrhoea, Viral Hepatitis, Dysenteries, Hookworm, Guinea worm diseases, and other infections could be contacted as a result of poor state of facilities in a house.

Studies have shown that there is an increase in demand for modern on-campus housing in today's environment of higher education institutions due to a high number of students who enroll yearly (Najib and Yusuf, 2009; Khozaei, Hassan and Khozaei, 2010). In the same vein, Sharma (2012) reveals that an estimated figure of about $160 \%$ increase in students' enrollment into tertiary education has been recorded globally.

Scholars have contended that occupants' perception of living and/or working environment defines the quality of their individual lives (Andrews and Whitney cited in Ogu, 2002). There are shreds of evidence in the literature that show that the academic performance of occupants of on-campus housing is influenced by an array of subjectively and objectively perceived housing conditions (Theodori, 2001). Onibokun (1990) observed that the habitability of a house by human beings was not only influenced by the engineering configuration of the house, but also by some social-cultural and environmental characteristics within the eco-system. The study noted that the house was only one variable among the factors that determined students' relative performance.

Furthermore, it is important to note that housing is not restricted to the individual's dwelling unit. Rather, it is a combination of the entire physical and social-economic components that make up the housing system (Francescato, Weidemman and Anderson 1989). The occupant's performance is also influenced by numerous components in the housing system. Some specific factors that have been found to have highly influenced occupant's performance, including students, 
generally include the age of a house (Varady and Preiser, 1998; Varady et al. 2001), physical characteristics of a house and facilities that are available (Yeh, 1972), satisfaction with management services (Varady and Carrozza, 2000), social interaction and relationship with neighbours (Varady and Preiser, 1998), residential mobility, as well as closeness to the workplace (Morshidi, Abdul Fatah, Abdul Rashid, Alip, Halim and Usman, 1970; Yeh, 1972).

\section{METHODOLOGY}

The research methodology adopted for this study was through the collection of primary data from the undergraduate residents of the Federal University of Technology, Akure, Nigeria. Secondary data were collected from peer-reviewed journals and the university library. The available literature on the quality of students' hostels in the study area revealed that the nine (9) hostels in the study area had different degrees of quality characteristics. The information further revealed that all the nine (9) undergraduate hostels were accommodating 2387 undergraduate students (FUTA students Affairs Division, 2019). These hostels include Akindeko hostel (male), Main Jibowu hostel (female), Jibowu Annex 1 (female), Jibowu Annex 2 (female), Jibowu Annex 3 (female), Jadesola hostel (female), Peter Adeniyi hostel (male), FUTA SCOOP hostel (female) and MKO Abiola hostel (male). The sample frame for the study was 2387 undergraduate students that were allocated bed spaces. The study purposely selected 180 students ( 20 from each hostel) for the sample using a simple random technique. The reason for making an equal selection of 20 students from each hostel was because it was assumed that the general characteristics of the populations of the hostels were similar. Conducting the survey, the interval of one (1) every five (5) rooms in each of the hostels was selected. Students in their first year of study were excluded from participating in the study because they had not obtained a cumulative grade point average (CGPA) as at the time of the study.

Legal occupants were targets of questionnaire administration in each of the sampled hostels. Information collected from them was on their length of stay in the hostel, their level of study, their opinion on the quality and conditions of facilities provided in their halls of residence, their academic performance before and during their stay in the university hostel. In all, 180 questionnaires were administered, out of which 147 representing $81.7 \%$ were valid and worthy for analysis in this study (This is shown in Table 2). This placed a non-response rate at $18.3 \%$ of the targeted respondents who were either not available or refused to supply information related to issues of their academic performance. Data collected were analysed using Weighted Mean Score (WMS), frequency distribution and regression analysis. The quality of the housing units was assessed using a Housing Quality Index as identified by Goodman (1978). 
Table 1. The List of Undergraduate Hostels in FUTA with their Location and Population

\begin{tabular}{clllc}
\hline S/No & Name of Hostel & Gender & Location & Population \\
\hline 1 & Main Jibowu hall & Female & Obanla & 570 \\
2 & Jibowu Annex 1 & Female & Obanla & 108 \\
3 & Jibowu Annex 2 & Female & Obanla & 80 \\
4 & Jibowu Annex 3 & Female & Obanla & 80 \\
5 & MKO Abiola hall & Male & Obanla & 300 \\
6 & Peter Adeniyi hall & Male & Obanla & 184 \\
7 & Jadesola hall & Female & Obanla & 229 \\
8 & FUTA SCOOP & Female & Obanla & 200 \\
9 & Gabriel Akindeko hall & Male & Obakekere & 636 \\
& & & & Total $=\mathbf{2 3 8 7}$ \\
\hline
\end{tabular}

Field survey, 2020

\section{RESULTS AND DISCUSSION}

\subsection{Questionnaire Distribution}

The data collated for this study comprises the primary data which were collated in the field with the use of questionnaires administered to the undergraduate students occupying hostels of the Federal University of Technology, Akure. The distribution and retrieval of the questionnaires are as shown below.

Table 2. The Number of Questionnaires Administered and Retrieved

\begin{tabular}{llll}
\hline Respondent & Number distributed & Number retrieved & Percentage \\
\hline Occupants (students) & 180 & 147 & 81.7 \\
\hline Field survey, 2020 & & &
\end{tabular}

From the total number of 180 questionnaires administered, 147 were retrieved, representing $81.7 \%$. It shows a good response from the respondents.

\subsection{Analysis of Questionnaires}

Table 3. The Percentage and Frequency Distribution of the Retrieved Questionnaires

\begin{tabular}{lcc}
\hline Hostels & Frequency & Percent \\
\hline Jibow Annex 3 & 11 & 7.5 \\
Jibow Annex 2 & 18 & 12.24 \\
Jibow Annex 1 & 17 & 11.56 \\
Adeniyi & 20 & 13.61 \\
FUTASCOOP & 12 & 8.16 \\
Jadesola & 17 & 11.56 \\
Abiola & 17 & 11.56 \\
Akindeko & 20 & 13.61 \\
\hline
\end{tabular}




\begin{tabular}{lcc}
\hline Main Jibowu & 14 & 9.52 \\
Total & $\mathbf{1 4 7}$ & $\mathbf{1 0 0 . 0}$ \\
\hline Field survey, 2020 & &
\end{tabular}

The table above shows a total number of nine (9) hostels with various rates of responses. All the responses were found valid and thus suitable for analysis. It shows a very good rate of response as it enables access to a wide range of data, thus resulting in fair research findings.

\subsection{Analysis of the Quality of Hostel Facilities}

Table 4 shows respondents' perception of the condition of the hostel facilities.

Table 4. Respondents' Evaluation of the Condition of the Hostel Facilities

\begin{tabular}{|c|c|c|c|c|c|c|c|c|}
\hline S/No & Facility & $\begin{array}{l}\text { VB } \\
1\end{array}$ & $\begin{array}{l}\text { B } \\
2\end{array}$ & $\begin{array}{l}\mathbf{F} \\
\mathbf{3}\end{array}$ & $\begin{array}{c}G \\
4\end{array}$ & $\begin{array}{l}\text { VG } \\
5\end{array}$ & WMV & $\begin{array}{l}\text { Ranking } \\
\text { of the } \\
\text { WMVs }\end{array}$ \\
\hline 1 & Security & 13 & 17 & 51 & 47 & 19 & 3.2857 & $4^{\text {th }}$ \\
\hline 2 & Power & 1 & 3 & 17 & 46 & 79 & 4.3630 & $1^{\text {st }}$ \\
\hline 3 & Water & 5 & 11 & 44 & 57 & 30 & 3.6531 & $2^{\text {nd }}$ \\
\hline 4 & Refuse & 13 & 19 & 44 & 53 & 17 & 3.2877 & $3^{\text {rd }}$ \\
\hline 5 & Drainage & 25 & 29 & 48 & 30 & 15 & 2.8707 & $5^{\text {th }}$ \\
\hline 6 & $\begin{array}{l}\text { Sewage } \\
\text { Management }\end{array}$ & 29 & 28 & 44 & 35 & 9 & 2.7724 & $6^{\text {th }}$ \\
\hline 7 & $\begin{array}{l}\text { Recreational } \\
\text { Facility }\end{array}$ & 53 & 34 & 34 & 21 & 2 & 2.2014 & $7^{\text {th }}$ \\
\hline 8 & $\begin{array}{l}\text { First } \\
\text { service }\end{array}$ & 58 & 34 & 30 & 23 & 1 & 2.1438 & $8^{\text {th }}$ \\
\hline
\end{tabular}

Note: $1=\mathrm{VB}=$ Very Bad, $2=\mathrm{B}=\mathrm{Bad}, 3=\mathrm{F}=$ Fair, $4=\mathrm{G}=\mathrm{Good}, 5=\mathrm{VG}=$ Very Good Field Survey, 2020

Table 4 shows the analysis of the respondents' perception of various hostel facilities in the undergraduate hostels at the Federal University of Technology, Akure. The researcher tried to investigate the Housing Quality Index (HQI) of the undergraduate hostel facilities to estimate their impact on the overall academic performance of the occupants (students). Data were collated via questionnaires and a 5-point Likert scale was used. Weighted Mean Value (WMV) was employed by the researcher to estimate the current quality index of the hostel facility. From the analysis, the lowest-ranked facilities included first aid, recreational facilities and drainage services with the weighted mean values of $2.1438,2.2014,2.7724$ and 2.8707 , respectively. These 4 facilities fell within the range of 2.0, i.e., 4 facilities were of bad condition. The security service, water supply and refuse management were all found to be of fair condition with weighted mean values of 3.2857, 3.6531 and 3.2877, respectively. Power supply was ranked first among the investigated facilities with a weighted mean value of $\mathbf{4 . 3 6 3 0}$, i.e., power supply in the undergraduate hostels was very good. The overall Housing Quality Index of the undergraduate hostels, which is the mean of the summation of the weighted mean values of the facilities considered, was 3.07. However, it is just an average figure 
and thus not good enough to lead to serious improvement on the occupants' academic performance.

\subsection{Analysis of the Quality of the Building Elements in the Hostels}

Table 5 shows the respondents' perception of housing elements.

Table 5. The Respondents' Perception of Building Elements

\begin{tabular}{|c|c|c|c|c|c|c|c|c|}
\hline \multirow{3}{*}{ S/No } & \multirow{3}{*}{$\begin{array}{l}\text { Building } \\
\text { elements }\end{array}$} & \multicolumn{5}{|c|}{ Rating and weighted values } & \multirow{3}{*}{ MWV } & \multirow{3}{*}{$\begin{array}{l}\text { Ranking of } \\
\text { building } \\
\text { elements }\end{array}$} \\
\hline & & VB & B & $\mathbf{F}$ & $\mathbf{G}$ & VG & & \\
\hline & & 1 & 2 & 3 & 4 & 5 & & \\
\hline 1 & Roof & 22 & 54 & 39 & 15 & 15 & 3.3655 & $7^{\text {th }}$ \\
\hline 2 & Wall & 24 & 54 & 50 & 11 & 8 & 3.5102 & $3^{\text {rd }}$ \\
\hline 3 & Floor & 4 & 10 & 56 & 53 & 24 & 3.5646 & $2^{\text {nd }}$ \\
\hline 4 & Door & 13 & 22 & 55 & 48 & 9 & 3.1224 & $10^{\text {th }}$ \\
\hline 5 & Window & 14 & 23 & 62 & 33 & 14 & 3.0685 & $12^{\text {th }}$ \\
\hline 6 & Painting & 19 & 25 & 62 & 32 & 6 & 2.8681 & $13^{\text {th }}$ \\
\hline 7 & Staircase & 6 & 10 & 28 & 37 & 17 & 3.5000 & $4^{\text {th }}$ \\
\hline 8 & Toilets & 57 & 40 & 26 & 15 & 7 & 2.1379 & $16^{\text {th }}$ \\
\hline 9 & Bathrooms & 42 & 38 & 44 & 16 & 7 & 2.3741 & $15^{\text {th }}$ \\
\hline 10 & Ceiling & 12 & 9 & 54 & 53 & 18 & 3.3836 & $5^{\text {th }}$ \\
\hline 11 & Ventilation & 9 & 18 & 47 & 56 & 17 & 3.3673 & $6^{\text {th }}$ \\
\hline 12 & Lighting & 5 & 16 & 45 & 53 & 27 & 3.5548 & $1^{\mathrm{st}}$ \\
\hline 13 & Common Room & 11 & 18 & 61 & 45 & 12 & 3.1973 & $9^{\text {th }}$ \\
\hline 14 & Reading Room & 9 & 25 & 55 & 33 & 10 & 3.0758 & $11^{\text {th }}$ \\
\hline 15 & $\begin{array}{l}\text { Population in } \\
\text { room }\end{array}$ & 14 & 22 & 38 & 49 & 23 & 3.3082 & $8^{\text {th }}$ \\
\hline 16 & Noise level & 43 & 32 & 45 & 18 & 6 & 2.3889 & $14^{\text {th }}$ \\
\hline \multicolumn{9}{|c|}{ Total WMV $=49.79$} \\
\hline \multicolumn{9}{|c|}{ MEAN OF $\sum W M V=49.79 / 16=3.11$} \\
\hline
\end{tabular}

Note: $1=\mathrm{VB}=$ Very Bad, $2=\mathrm{B}=\mathrm{Bad}, 3=\mathrm{F}=$ Fair, $4=\mathrm{G}=$ Good, $5=\mathrm{VG}=$ Very Good Field survey, 2020

Table 5 shows the analysis of the occupants' perception of the quality of the housing elements in the undergraduate hostels at the Federal University of Technology, Akure.

Core building elements of the hostels were investigated in the study to assess their current condition in terms of quality. The bathrooms, toilets, noise levels (acoustic) and the paintings on the buildings were found to be in bad condition based on their weighted mean values as shown in the table above. On the other hand, lighting in the hostels, floor, walls, staircases, ceilings, ventilation, roof, the rooms size, condition of common rooms, doors, reading rooms and windows were all found to be of fair quality. The lighting in the hostels was found to have the highest weighted mean value of 3.5548 (a fair value), while the toilets were found to be of lowest quality with a weighted mean value of 2.1379 .

The overall Housing Quality Index of the hostels, which is the mean of the summation of the weighted mean values of the hostels, was estimated to be 3.11 . 
The result of this study showed that the quality of the building elements in the undergraduate hostels was fair and might have a weak influence on the academic performance of the students.

\subsection{Analysis of the Academic Performance of the Occupants of the University Hostels}

Table 6 shows the frequency and percentage of occupants' Cumulative Grade Point Average (CGPA) before moving to the university hostel.

Table 6. The Frequency of Occupants' Cumulative Grade Point Average before Moving to the University Hostel

\begin{tabular}{lll}
\hline CGPA & Frequency & Percent \\
\hline $4.5-5.0$ & 21 & 15.6 \\
$3.5-4.49$ & 60 & 44.4 \\
$2.5-3.49$ & 53 & 39.3 \\
$1.0-2.49$ & 1 & 0.7 \\
Total & $\mathbf{1 3 5}$ & $\mathbf{1 0 0}$ \\
\hline Field Survey, 2020 &
\end{tabular}

Table 7 shows the frequency of occupants' Cumulative Grade Point Average after moving to the university hostel.

Table 7. The Frequency of Occupants' Cumulative Grade Point Average after Moving to the University Hostel

\begin{tabular}{lll}
\hline CGPA & Frequency & Percent \\
\hline $4.5-5.0$ & 31 & 22 \\
$3.5-4.9$ & 66 & 46.8 \\
$2.5-3.49$ & 44 & 31.2 \\
$1.0-2.49$ & - & 0.0 \\
Total & $\mathbf{1 4 1}$ & $\mathbf{1 0 0}$ \\
\hline Field survey, 2020 &
\end{tabular}

Based on the analysis of the academic performance of the occupants of the undergraduate hostels in Tables 6 and 7, it was discovered that out of 147 students with valid data analysed, 135 of the respondents revealed their CGPA before moving to the on-campus hostels. Out of these numbers, none had a CGPA below 1.0; however, one student was in Third Class grade with a CGPA that ranged from 1.0 to 2.49 representing $0.7 \%$. Furthermore, 53 students were observed to be in Second Class (2.2) grade with CGPAs between 2.50 to 3.49 representing $39.3 \%$, 60 students were in Second Class Upper (2.1) grade with CGPAs of 3.50 to 4.49 representing $44.4 \%$. In a similar vein, 21 students were in the First Class division before moving to the hostel with CGPAs of 4.50 to 5.00 (15.6\%).

Looking at their current CGPAs after spending at least a session in the oncampus hostels, it was found that none had a CGPA below 1.0; none was in the Third Class with a CGPA between 1.0 to 2.49 representing $0 \%$. Furthermore, 44 
students were observed to be in Second Class Lower (2.2) with CGPAs between 2.50 to 3.49 representing $31.2 \%$, 66 students moved to Second Class Upper (2.1) with CGPAs of 3.50 to 4.49 representing $46.8 \%$, while 31 students were in the First Class division with CGPAs of 4.50 to $5.00(22 \%)$. The analysis revealed that there was a positive influence on occupants' academic performance arising from the quality of the housing and the facilities in the undergraduate hostel of the university. This is essentially attributed to the good quality of power supply at the university as well as fair housing quality indices as revealed in the study.

\subsection{Regression Analysis of the Influence of Housing Quality on the Academic Performance of the Occupants of the Hostel}

Table 8 shows the model summary of the regression analysis.

Table 8. Model Summary

\begin{tabular}{lllll}
\hline Model & $\boldsymbol{R}$ & $\boldsymbol{R}$ Square & Adjusted $\boldsymbol{R}$ Square & Std. Error of the Estimate \\
\hline 1 & $0.377^{\mathrm{a}}$ & 0.142 & -0.054 & 0.67240
\end{tabular}

a. Predictors: (Constant), Noise level, Wall, Common Room, Staircase, Ventilation, Population in the room, Reading Room, Lighting, Toilets, roof, Painting, Floor, Window, Ceiling, Door, Bathrooms

Field survey, 2020

Table 9 shows the coefficient table of the analysis.

Table 9. Coefficients

\begin{tabular}{llllll}
\hline \multirow{2}{*}{ Model } & \multicolumn{3}{l}{ Unstandardised coefficients } & \multicolumn{3}{l}{ Standardised coefficients } \\
& $\boldsymbol{B}$ & Std. Error & Beta & $\boldsymbol{T}$ & Sig. \\
\hline 1 (Constant) & 3.108 & 0.572 & & 5.432 & 0.000 \\
Roof & 0.089 & 0.087 & 0.160 & 1.020 & 0.311 \\
Wall & 0.018 & 0.131 & 0.027 & 0.139 & 0.890 \\
Floor & -0.082 & 0.140 & -0.110 & -0.585 & 0.560 \\
Door & -0.029 & 0.120 & -0.046 & -0.238 & 0.812 \\
Window & -0.090 & 0.107 & -0.157 & -0.842 & 0.403 \\
Painting & 0.021 & 0.096 & 0.034 & 0.221 & 0.826 \\
Staircase & -0.013 & 0.077 & -0.022 & -0.170 & 0.866 \\
Toilets & 0.151 & 0.128 & 0.270 & 0.179 & 0.242 \\
Bathrooms & -0.065 & 0.126 & -0.116 & -0.517 & 0.606 \\
Ceiling & 0.021 & 0.114 & 0.033 & 0.182 & 0.856 \\
Ventilation & 0.016 & 0.090 & 0.024 & 0.176 & 0.861 \\
Lighting & -0.129 & 0.106 & -0.186 & -1.213 & 0.229 \\
Common Room & -0.104 & 0.101 & -0.133 & -1.032 & 0.305 \\
Reading Room & -0.091 & 0.096 & -0.126 & -0.941 & 0.350 \\
Population in room & -0.001 & 0.077 & -0.002 & -0.017 & 0.986 \\
Noise level & 0.009 & 0.071 & 0.015 & 0.121 & 0.904 \\
\hline
\end{tabular}

a. Dependent Variable: Current CGPA

Field survey, 2020 
The table above shows the regression output of occupants' current CGPA against the building elements. The regression coefficients show the relationship between a dependent variable and independent variables. Beta coefficients show the amounts by which a unit change in the quality of building elements would bring to the CGPA of occupants. The variables with positive values imply a positive impact while those with negative values connote a negative correlation.

The analysis above thus implies that there is a weak relationship between the housing quality indices and the students' academic performance.

Table 10 shows the residuals of the analysis

Table 10. Residual Statistics

\begin{tabular}{llllll}
\hline & Minimum & Maximum & Mean & Std. Deviation & $\boldsymbol{N}$ \\
\hline Predicted value & 1.3849 & 2.5427 & 2.0345 & 0.24704 & 87 \\
Residual & -1.33189 & 1.35644 & 0.00000 & 0.60663 & 87 \\
Std. Predicted value & -2.629 & 2.057 & 0.000 & 1.000 & 87 \\
Std. Residual & -1.981 & 2.017 & 0.000 & 0.902 & 87 \\
\hline
\end{tabular}

a. Dependent Variable: Current CGPA

Field survey, 2020

In the regression analysis presented in the tables above, the regression coefficient was used to establish the relationship between the qualities of the variables constituting the building elements and the Cumulative Grade Point Average (CGPA) of occupants of the on-campus hostels.

The coefficient of regression $R$ showed that $r=0.377, p \leq 0.05$. This regression demonstrates that there is a relationship between the quality of the on-campus hostels and the CGPA of the occupants of the hostels. The variable $(R$ Squared $=$ 0.142 ) shows that a $14.2 \%$ change in the housing quality will bring a unit change in the CGPA of the occupants. This implies that there is a weak relationship between the quality of building elements and the academic performance of the students.

\section{FINDINGS}

Based on the analysis of the data collated, the major findings as deduced from the results are summarized below.

The assessment of the Housing Quality Indices of the on-campus hostels showed that the quality of the hostels was fair with the weighted mean value of the hostels being 3.11.

In a similar vein, the quality index of the hostel facilities was deduced to be 3.07. This was estimated via the weighted mean value of the facilities in the nine undergraduate on-campus hostels investigated.

Furthermore, the academic performance of the occupants was assessed based on the current and past academic performance before and after moving to the oncampus hostels. The study revealed that $15.6 \%$ of the occupants were in the First Class before moving to the university hostel, while $44.4 \%$ were in the Second Class 
Upper, $39.3 \%$ were in the Second Class Lower, while $0.7 \%$ were in the Third Class grades. The study further revealed that 44 students representing $31.2 \%$ were observed to be in the Second Class Lower division with CGPAs between 2.50 to 3.49; 66 students representing $46.8 \%$ moved to the Second Class Upper division with CGPAs of 3.50 to 4.49 , while 31 students representing $22 \%$ were in the First Class division with CGPAs of 4.50 to 5.00 .

The regression analysis was carried out to find out the relationship between housing quality, quality of hostel facilities and academic performance of the students of on-campus hostels. The deduction showed that there was a positive relationship between the academic performance of the occupants, the housing quality and the quality of housing facilities, but the quality of facilities was more influential on the occupants' academic performance than the quality of housing elements.

There was a noticeable improvement in the performance of the occupants after spending at least a session in the hostel as the number of first-class students rose to $22 \%$, Second Class Upper increased to $46.8 \%$, those in Second Class Lower reduced to $31.2 \%$ while there was no sampled occupant in the on-campus hostel that had a CGPA of less than 2.49.

The major factor contributing to this improvement in the academic performance of the students residing in the on-campus hostels was adequacy of power supply, which was rated "good", the highest ranking among all building elements as well as among the hostel facilities reviewed with a weighted mean value of 4.3630 . This is rational and quite understandable because most students depend on the availability of power supply for reading, research, assignments and all related activities that contribute to their academic success.

\section{RECOMMENDATIONS}

1. This study has revealed that the quality of the facilities in the on-campus housing is not of the best standard to promote high academic excellence; therefore, the government in collaboration with the universities should carry out a comprehensive renovation of the hostels to meet the minimum standard for habitable living as set by the United Nations.

2. Introduction of a strategic management maintenance programmes for the oncampus students' housing will help preserve the quality of buildings and facilities. To this end, certified estate managers should be engaged in the management and maintenance of the on-campus hostel buildings and facilities.

3. Universities should partner with private investors and charity organisations to build more on-campus hostels with adequate facilities to accommodate more students in the campus. This will contribute to the academic improvement of the students and at the same time enhance the university ranking and national development in the long run. 


\section{CONCLUSION}

This study has assessed the current housing quality indices of university hostel facilities and the building elements at the Federal University Akure, Nigeria. It has also investigated the academic performance of the undergraduate students' before moving to the on-campus hostels and their performance after at least a session in the on-campus housing to deduce the impact of on-campus housing quality on their academic performance.

The study has adopted the regression analysis to test the impact of the hostel conditions and the quality of facilities on the academic performance of the occupants. The deduction has shown that a relationship exists between the academic performance of the occupants, the housing quality and the quality of housing facilities, but the quality of facilities in the houses is more influential on the students' academic performance than the quality of the housing elements.

Therefore, every effort should be made by the university authority and other relevant stakeholders such as the federal government, private organisations etc. to ensure the provision of sufficient and quality on-campus housing with efficient management programmes for a radical academic improvement of students at the university.

\section{Data Availability Statement}

All data, models, and code generated or used during the study appear in the submitted article.

\section{REFERENCES}

Abramson, P. (2009). Living on campus. Downsizing residence halls: Space and costs. College Planning. Management. Mag., 12, 2027.

Adeleye, O., Akinpelu, O. P., and Azeez, T. O. (2018). Students' housing satisfaction in selected public tertiary institutions in Oyo State, Nigeria. International Journal of Economics, Commerce and Management, 6(5), 712-725.

Agbo, H. A, Envuladu, E. A., Adah, U. G., and Zoakah, A. I. (2012). An assessment of toilet facilities in secondary schools in Jos North Local government area of plateau state. Green Journal of Educational Research, 2(4), 91-94. https://doi.org/10.15580/GJER.2012.4.110112199

Agbola, T., and Oladoja A. (1988). Philosophy and Theory of Urban and Regional Planning. In Agbola, T. (Ed.) Reading in Urban and Regional Planning. Ibadan Nigeria, Macmillan.

Aluko, O. E. (2011). The assessment of Housing Situation among Students in theUniversity of Lagos. African Research Review, 5(3), 104118. https://doi.org/10.4314/afrrev.v5i3.67345

Amole, D. (2009). Residential satisfaction in students' housing. J. Environmental Psychology, 29(1), 76-85. https://doi.org/10.1016/j.jenvp.2008.05.006

Bender, T. (1988). The University and the City. From Medieval Origins to the Present. Oxford University Press.

Brkanic, I. (2017). Housing Quality Assessment Criteria. Available from: http://egfos.gfos.hr/app/storage/protected/42-30-06-2017-10-42-21-paper-5-brkanic.pdf [accessed 23/05/2019]. https://doi.org/10.13167/2017.14.5

Caldenby, C. (1994). Universitetet Och Staden, White Coordinator Pabygget, Alvesta.

Centre for Global Education (2002). Available from: https://www.centreforglobaleducation.com/global 
Chartered Institute of Public Health (2008). Good housing leads to good health: A toolkit for environmental health practioner. Chadevick Court, 15 Hatfields, London, UK.

Danes, S. M., and Morris, E. W. (1986). Housing status, housing expenditures and satisfaction with housing quality. Housing and Society, 13(1), 32-43. https://doi.org/10.1080/08882746.1986.11429976

Dahlan, N. D., Jones, P. J., Alexander, D. K., Salleh, E., and Alias, J. (2009). Evidence base prioritization of indoor comfort perceptions in Malaysian typical multi-story hostels. Buil. Environ., 44(10), 2158-2165. https://doi.org/10.1016/j.buildenv.2009.03.010

Deji-Folutile, O., and Oketola, D. (2014). Government houses are costlier than NigerianUniversities. Punch Newspaper, November 8, 2014.

Ebie, S. P. (2009). Public sector driven housing: Achievement and problems. Paper presented at the 2009 Fcaculty of Environmental Sciences Annual lecture, Nnamdi Azikiwe University, Awka Nigeria.

Ebong M. O. (1983). The Perception of Residential Quality: A case study of Calabar, Nigeria. Third World Planning Review, 5(3), 273-284. https://doi.org/10.3828/twpr.5.3.d788q6x8m180t4h8

Ezeigwe, P. (2015). Evaluation of the causes of housing problems in Nigeria. A case study of Awka, the capital city of Anambra state. Journal of Economics and Sustainable Development, 6(20), 1-7.

Francescato, G., Weidemman, S., and Anderson, R. J. (1989). Evaluating the built environment from the user's point of view: an attitudinal model of residential satisfaction. In Preiser W. F. E. (eds.) Building Evaluation. Springer, Boston. https://doi.org/10.1007/978-1-4899-3722-3 14

Foubert, J. D., Tepper, R., and Morrison D. R. (1998). Predictors of student satisfaction inuniversity residence halls. J. College Univ. Student Housing, 21, 41-46.

Goodman, Jr. J. L. (1978). Causes and Indicators of Housing Quality. Social IndicatorsResearch, 5(2), 195-210. https://doi.org/10.1007/BF00352929

Hanmer, L., Booth, D., and Love, E. (2000). Poverty and Transport. A report prepared for the World Bank in collaboration with DFID, Overseas Development Institute.

Hassanain, M. A. (2008). On the performance evaluation of sustainable student housing facilities. Journal of Facilities Management, 6(3), 212-225. https://doi.org/10.1108/14725960810885989

Hofstede, G. (1984). The cultural relativity of the quality of life concept. Acad. Manage. Rev., 9(3), 389-398. https://doi.org/10.5465/amr.1984.4279653

Hunley, S. S. (2006). Assessing learning spaces. In Oblinger D. G. (Eds.). Learning Spaces, Educause.

Jacobs, D. E., Clickner, R. P., Zhou, J. Y., Viet, S. M., Marker, D. A., Rogers, J. W., Zeiden, D. C., Broene, P., and Friedman, W. (2002). The prevalence of lead-based paint hazards in U.S. housing. Environ Health Perspectives, 110(10), A599-A606. https://doi.org/10.1289/ehp.021100599

Kaya, N., and Erkip, F. (2001). Satisfaction in a dormitory building: The effects of floor on the perception of room size and crowding. Environment and Behavior, 33(1), 35-53. https://doi.org/10.1177/00139160121972855

Kellekci, O. L., and Berkoz L. (2006). Mass Housing: User satisfaction in housing and its environment in Istanbul, Turkey. Eur. J. House Policy, 6(1), 77-99. https://doi.org/10.1080/14616710600587654

Khozaei, F., Ayub, N. Hassan, A. S., and Khozaei Z. (2010). The factors predicting students' satisfaction with university hostels, Case Study, Universiti Sains Malaysia. Asia Culture History, 2(2), 148-158. https://doi.or g/10.5539/ach.v2n2p148

Kuh, G. D., Kinzie, J., Buckley, J., Bridges, B. K and Hayek, J. C. (2006). What matters to students' success: A review of the literature. Commissioned report for the national symposium on postsecondary student success. National post-secondary education cooperative.

Longman, D. (2003). Dictionary of contemporary English. (Eds) Fox C. E., Murphy, M., Urban, R., Marwick, K. C. Parson Education Limited.

Mbano-Pat, E. C., Alaka, I. N., and Okeoma, I. O. (2012). Examining the Physio, psycho, andsocioeconomic implications of non-residency policy on Imo State University Students. Canadian Social Sciences, 8(2), 170-179. 
Mbano-Pat, E. C., Alaka, I. N., and Ewulum, N. J. (2012). Contributions of private hostel developers to meeting the housing needs of Imo State University Students at Ugwuorji Owerri, Nigeria. Canadian Social Sciences, 8(2), 161-169.

Meng, G., and Hall, G. B. (2006). Assessing housing quality in Metropolitan Lima, Peru. Journal of housing and the built environment, 21, 413-439. https://doi.org/10.1007/s10901-006-9058-1

Morris, E. W., Winter, M., \& Murphy, A. D. (1988). Housing adjustment, satisfaction -and quality/quantity considerations in housing: The case of Oaxaca de Juarez. Proceedings of the 1988 Annual Conference of the Environmental Design Research Association, Pomona, California.

Morshidi, S., Abdul Fatah, H., Abdul Rashid, A., Alip, R., Halim, S., Usman, Y. (1970). Low-cost housing in urban-industrial centers of Malaysia: issues and challenges. Penang: Universiti Sains Malaysia Bookshop Ltd.

Najib, N. U., and Yusof, N. A. (2009). A review of student housing facilities in a higher learning institution. Proceeding of the 3rd International Conference on Built Environment in Developing Countries (ICBEDC 2009), Dec. 2-3, Malaysia, pp. 1817-1831.

Ndubueze, O. (2001). Problem of Public Housing Estate in Nigeria. Journal of the Nigeria Institute of Town Planners, XIV, 11-23.

Neilson, M. (2004). Scottish housing quality standard (SHQS). Scottish executive development department.

Ogu, V. I. (2002). Urban residential satisfaction and the planning implications in adeveloping world context: the example of Benin City, Nigeria. International Planning Studies, 7(1), 37-53. https://doi.org/10.1080/13563470220112599

Okewole, I. A., and Aribigbola, A. (2006). Innovations and sustainability in housing policy conception and implementation in Nigeria. In: The built environment: innovation, policy and sustainable development. I. A. Okewole, A. Ajayi, A. Daramola, K. Odunsanmi and O. Ogunba (Eds). Covenant University, Ota, Ogun State, Nigeria. pp. 414-420 .

Oladapo A. A. (2006). A Study of Tenant Maintenance Awareness, Responsibility and Satisfaction in Institutional Housing in Nigeria. International Journal of Strategic Property Management, 10(4), 217-231. https://doi.org/10.3846/1648715X.2006.9637554

Olujimi, J., and M. O. Bello, (2009). Effects of infrastructural facilities on the rental values of residential property, J. Soc. Sci., 5(4), 332-341.

Oluwunmi, A. O., Akinjare, O. A., and Izobo-Martins, O. O. (2012). User's satisfaction with residential facilities in Nigerian private Universities: A study of Covenant University. Transnational Journal of Science and Technology, 2(11), 89-112.

Onibokun, P. (1990). Socio-cultural Constraints on Urban Renewal Policies in Emerging Nations. The Ibadan Case, pp. 393-405. In: Housing in Nigeria. P. Onibukun (Ed.). A Book of Reading (NIER), Ibadan.

Owolabi, B. O. (2015). The Effects of Students' Housing on Academic Performance at the University of Ibadan in Nigerian. International Journal of Scientific \& Engineering Research, 6(3), 1119-1132.

Schenke, J. (2008). Purdue students prefer to go solo. College Planning. Manage., 11, 62-64.

Sharma, Y. (2012). Fast pace of higher education enrolment predicted to slow. University World news Issue No. 213.

Susilawati, C. (2001). Student dormitory development plan with a linear programming method. Proceeding of the PRREs $7^{\text {th }}$ Annual Conf. (PRREsAC' 01). Surabaya, Indonesia, pp. 1-11.

Theodori, G. L (2001). Examining the effects of community satisfaction and attachment on individual well being. Rural Sociology, 66(4), 618-628. https://doi.org/10.1111/j.15490831.2001.tb00087.x

Torres-Antonini, M., and Park, N. K. (2008). Sustainable student campus housing in the USAsia Interior Design Institute Assoc. (AIDIA), Seoul, Korea. Int. J. Spatial Design Res., 8, 29-38.

UK Houses of Paliament (2011). Housing and Health. The Paliamentary office of Science and Technology, 7 Millbank, London.

United Nations (2003). The Right to Adequate Housing. Centre for Human Rights, Geneva. 
Varady, D. P., and Preiser W. F. E (1998). Scattered-site public housing and housingsatisfaction: implications for the new public housing program. Journal of American Planning Association, 64(2), 189-207. https://doi.org/10.1080/01944369808975975

Varady, D. P. and Carrozza, M. A. (2000). Towards a better way to measure customer satisfaction levels in public housing: A report from Cincinnati. Housing studies, 15(6), 797-825. https://doi.org/10.1080/02673030020002555

Varady, D. P., Walker, C. C., and Wang, X. (2001). Voucher recipient achievement of improvedhousing conditions in the US: do moving distance and relocation services matter? Urban Studies, 38(8), 1273-1305. https://doi.org/10.1080/00420980124918

World Health Organization for Healthy Living (1988). Indoor Air Quality: Radon and Formaldehyde: Report on a World Health Organization Meeting.

Yeh, S. H. K. (1972). Homes for the People: A Study of Tenants' Views on Public Housingin Singapore. University of Singapore: Economic Research Center. Peer-review under responsibility of Southeast University.

\section{AUTHORS' SHORT BIOGRAPHY}

David Ngwoke Mbazor is a Lecturer in the Department of Estate Management at the Federal University of Technology, Akure, Nigeria. He holds B. Tech. in Estate Management from the Federal University of Technology, Minna, Nigeria; Master of Business Administration from University of Calabar, Nigeria, and MSc in International Project Management from Glasgow Caledonian University, Scotland, the UK. His research interests are situated in the fields of sustainable housing development and management with focus on housing quality, real estate development, land administration and property/facility management. He is currently a Doctoral Candidate at SARChi Center of Sustainable Construction Management and Leadership in the Built Environment, Faculty of Engineering and the Built Environment, University of Johannesburg, South Africa.

E-mail: dnmbazor@,futa.edu.ng

ORCID iD: https://orcid.org/0000-0001-7437-8899 